UNELECTED POWER 



\title{
UNELECTED POWER
}

The Quest for Legitimacy in Central Banking and the Regulatory State

\author{
Paul Tucker
}

PRINCETON UNIVERSITY PRESS

Princeton \& $0 x$ ford 
Copyright ( $) 2018$ by Princeton University Press

Published by Princeton University Press,

41 William Street, Princeton, New Jersey 08540

In the United Kingdom: Princeton University Press, 6 Oxford Street, Woodstock, Oxfordshire OX20 1TR

press.princeton.edu

Jacket design by Faceout Studio

Jacket image courtesy of Shutterstock

All Rights Reserved

ISBN 978-0-691-17673-4

Library of Congress Control Number: 2018935378

British Library Cataloging-in-Publication Data is available

This book has been composed in Minion Pro text with Helvetica Neue LT Std display

Printed on acid-free paper. $\infty$

Printed in the United States of America

$\begin{array}{lllllllllll}10 & 9 & 8 & 7 & 6 & 5 & 4 & 3 & 2 & 1\end{array}$ 